\title{
Relationship between intracellular free magnesium concentration and the degree of insulin resistance in horses with equine metabolic syndrome
}

\author{
Judith C. Winter', Eva Müller', Gerhard Sponder², Roswitha Merle3, Jörg R. Aschenbach² and Heidrun Gehlen' \\ ' Equine Clinic: Surgery and Radiology, Freie Universität Berlin \\ 2 Institute of Veterinary Physiology, Freie Universität Berlin \\ ${ }^{3}$ Institute of Veterinary Epidemiology and Biostatistics, Freie Universität Berlin
}

\begin{abstract}
Summary: Magnesium metabolism, especially the intracellular magnesium concentration $\left[\mathrm{Mg}^{2+}\right]_{\mathrm{i}}$, plays an important role in human diabetes mellitus. The aim of this study was to evaluate $\left[\mathrm{Mg}^{2+}\right]_{i}$ in horses with insulin resistance and to examine a possible association with other markers of insulin dysregulation. The study included 38 horses with a positive combined glucose insulin tolerance test (CGIT) and phenotypic signs of EMS. Baseline glucose $\left(G_{0}\right)$, glucose curve, baseline insulin $\left(I_{0}\right)$, insulin after 45 minutes $\left(I_{45}\right)$, total serum magnesium concentration and $\left[\mathrm{Mg}^{2+}\right]_{i}$ were measured. The reciprocal inverse square of insulin (RISQI), the modified insulin-to-glucose ratio (MIRG) and the insulin difference ( $\left.I_{45-0}\right)$ were calculated. A t-test for independent samples was used to compare $\left[\mathrm{Mg}^{2+}\right]_{\mathrm{i}}$ in healthy and EMS horses. Linear regression analyses with uni- and multivariable models were calculated to evaluate the influence of $\left[\mathrm{Mg}^{2+}\right]_{i}$ on all other blood and clinical parameters. Compared to healthy controls, $\left[\mathrm{Mg}^{2+}\right]_{i}$ was significantly lower in horses with $E M S(P=0.015)$. Univariable linear regression models showed significant associations between $I_{0}(P=0.004, b=0.006), I_{45}(P=0.006, b=0.001), I_{45-0}(P=0.008, b=0.001), R I S Q I(P=0.009, b=-0.158), M I R G$ $(P=0.001, b=0.017)$ and $\left[\mathrm{Mg}^{2+}\right]_{i}$. The multivariable model revealed that MIRG significantly influenced $\left[\mathrm{Mg}^{2+}\right]_{i}$ whereas the other factors had no additional influence. Horses with EMS exhibited an intracellular magnesium deficit that can be partially reversed by increased secretion of insulin. These findings substantiate the crucial role for insulin in regulating $\left[\mathrm{Mg}^{2+}\right]_{i}$ and its relevance in EMS.
\end{abstract}

Keywords: magnesium, lymphocytes, insulin dysregulation, diabetes mellitus

Citation: Winter J. C., Müller E., Sponder G., Merle R., Aschenbach J. R., Gehlen G. (2020) Relationship between intracellular free magnesium concentration and the degree of insulin resistance in horses with equine metabolic syndrome. Pferdeheilkunde 36, 325-332; DOI 10.21836/ PEM20200406

Correspondence: Dr. Judith Christine Winter, Equine Clinic, Surgery and Radiology; Freie Universität Berlin, Oertzenweg 19b, 14163 Berlin, Germany; judithcwinter@gmail.com

Submitted: September 30, 2019 | Accepted: April 8, 2020

\section{Introduction}

Diabetes mellitus is a worldwide problem as is the equivalent equine metabolic syndrome (EMS). Key features of both diseases are insulin dysregulation (ID), chronic inflammatory state and dysfunction of the adipose tissue (Frank et al. 2010). Human diabetes mellitus type II patients often display a magnesium deficit in the serum or at the intracellular level and supplementation with magnesium can improve the insulin sensitivity (Volpe 2008, Günther 2010). Multiple reasons for magnesium deficits have been suggested in humans. Diabetes patients are more likely to consume an unhealthy diet with a low magnesium content (Paolisso and Barbagallo 1997). Additionally, losses of magnesium in the urine due to increased tubular flow and reduced tubular absorption in the kidney (hyperglycemic glycosuria) are possible (Ponder et al. 1990, Pham et al. 2007). Magnesium influences the tyrosine kinase at the insulin receptor and leads to an increased uptake of glucose into the tissue. Insulin, on the other hand, can induce a shift of magnesium from the extracellular fluid into the cell (Mastrototaro et al. 2015). Furthermore, under stress conditions (such as decreased insulin sensitivity), activation of various transporters like the magnesium transporter "solute carrier family 41, member A1" (SLC41A1) may result in active magnesium transport out of the cell. Insulin resistance may thus promote an intracellular magnesium deficiency (Mastrototaro et al. 2015, Romani and Maguire 2002) and this, in turn, could exacerbate the insulin resistance. Finally, magnesium deficiency could lead to a mismatch of calcium and magnesium. The latter results in increased vascular tone and increased secretion of catecholamines by sympathetic nerve endings (Itani et al. 2000). Ultimately, these changes trigger hypertension in humans and could play a role in equine laminitis as well.

Horses' diets typically contain high amounts of magnesium and baseline hyperglycemia with glycosuria and urinary losses of magnesium rarely occur (Stewart et al. 2004). A whole body magnesium deficit is therefore unlikely to develop. However, shifts from the intracellular to the extracellular level are reasonable, resulting in an intracellular magnesium deficit. 
The serum magnesium content contributes only $0.3 \%$ to the total body magnesium content. When the serum concentration is too low, shifts from the intracellular compartment to the serum keep the serum magnesium concentration within the reference range (Vormann 2003, Arnaud 2008). The serum magnesium concentration is therefore an insensitive method to evaluate the tissue magnesium concentration (Chaudhary et al. 2010). Tissue biopsies would be a more precise, but also more invasive procedure. The intracellular magnesium concentration $\left[\mathrm{Mg}^{2+}\right]_{\mathrm{i}}$ in blood lymphocytes (Princi et al. 1997, Delva et al. 2006), erythrocytes (Basso et al. 2000) or platelets (Niemela et al. 1997, Yoshimura et al. 1998) is similar to the concentration in the tissue. Therefore it has been used as a preferred marker of the magnesium metabolism (Princi et al. 1997). Methods to determine blood cell $\left[\mathrm{Mg}^{2+}\right]_{\mathrm{i}}$ (Reinhart et al. 1987, Schwinger et al. 1987) have been used in human medicine since the 1980s and reference values for $\left[\mathrm{Mg}^{2+}\right]_{i}$ in healthy horses have previously been established (Winter et al. 2018).

Measurements of $\left[\mathrm{Mg}^{2+}\right]_{i}$ in horses with ID could give new insights into a possibly altered magnesium metabolism and present a new diagnostic and research tool. Therefore, the aim of this study was to evaluate $\left[\mathrm{Mg}^{2+}\right]_{i}$ in horses with insulin resistance and to examine a possible association with other markers of insulin dysregulation. Proceeding from results in humans, we hypothesized that $\left[\mathrm{Mg}^{2+}\right]_{i}$ is inversely correlated with parameters of insulin resistance in EMS horses.

\section{Material and Methods}

\section{Horses}

In this study, 38 horses with different degrees of ID were examined. The horses were client-owned patients that were admitted to our clinic with an EMS phenotype between July 2016 and October 2017.

Criteria for inclusion were as follows: normal findings on clinical examination except for general and/or regional obesity; body condition score $(B C S) \geq 7$; cresty neck score $(C N S) \geq 3$; $\geq 4$ years of age; negative test results for pituitary pars intermedia dysfunction (normal plasma ACTH concentration); no acute laminitis; and no magnesium supplementation during the last three months. All subjects had to show insulin dysregulation in the combined glucose insulin tolerance test (CGIT) (prolonged time ( $\geq 90$ minutes) of the glucose curve to drop to baseline and/or increased baseline insulin $\left(\mathrm{I}_{0} ;>20 \mu \mathrm{U} / \mathrm{mL}\right)$ and/or increased insulin after 45 minutes $\left.\left(\mathrm{I}_{45} ;>100 \mu \mathrm{U} / \mathrm{mL}\right)\right)$.

\section{Experimental design}

After admission, body weight, height, CNS (Carter et al. 2009) and BCS (Henneke et al. 1983) were measured. Horses were acclimatized for at least 12 hours and fasted for another 6 hours. Blood sampling and the CGIT were performed the morning after arrival. Blood samples to determine triglycerides (TG), gamma-glutamyl transferase (GGT), fructosamine and the total serum and $\left[\mathrm{Mg}^{2+}\right]_{i}$ were taken immediately before the start of the CGIT. A clinical and orthopedic examination (including laminitis grading according to Obel 1948) were performed after completion of the CGIT.

\section{CGIT}

The evening before testing, an IV catheter (Infusion catheter Set G14, Walter Veterinär-Instrumente e.k., Baruth/Mark, Germany) was inserted into one of the jugular veins under local and antiseptical conditions. To determine baseline glucose $\left(G_{0}\right)$ and insulin $\left(I_{0}\right)$ concentrations, blood samples were collected from the jugular vein catheter immediately before the start of the CGIT into a blood collection syringe containing lithium heparin (BD A-Line $^{\mathrm{TM}}$, Arterial Blood Collection Syringe, Beckton, Dickinson and Company, Plymouth, United Kingdom) and tubes containing microscopic silica particles (EDTA tubes $4 \mathrm{ml}$ and Lithium heparin tubes $10 \mathrm{ml}$, Sarstedt AG \& Co, Nümbrecht, Germany). The CGIT procedure was conducted as described previously (Eiler et al. 2005). Briefly said, $150 \mathrm{mg} / \mathrm{kg}$ glucose (Glucose $40 \%$ ad us. vet., B. Braun Melsungen AG, Melsungen, Germany) and $0.1 \mathrm{mg} /$ $\mathrm{kg}$ porcine insulin (Caninsulin ${ }^{\circledR}$, Intervet Deutschland $\mathrm{GmbH}$, Unterschleißheim, Germany) were given IV. Glucose concentrations were measured after 1, 5, 15, 25, 35, 45, 60, 75, 90, 105, 120,135 and 150 minutes. Additionally, insulin was measured at 45 minutes $\left(I_{45}\right)$. $G_{0}$ and $I_{0}$ concentrations were used to calculate the proxies reciprocal inverse square of insulin (RISQI), a parameter for insulin sensitivity, modified insulin-to-glucose ratio (MIRG), a parameter for $\beta$-cell function (Treiber et al. 2005) and the homeostasis model assessment for insulin resistance (Fukushima et al. 1999, Kronfeld et al. 2005) index (HOMA-IR).

Intracellular magnesium concentration

Blood samples for the measurements of $\left[\mathrm{Mg}^{2+}\right]_{i}$ were collected into tubes containing lithium heparin (Lithiumheparin tubes $10 \mathrm{ml}$, Sarstedt AG \& Co, Nümbrecht, Germany). The samples were processed immediately to isolate equine blood lymphocytes and measure $\left[\mathrm{Mg}^{2+}\right]_{i}$ by spectrophotometry (LS 55 spectrophotometer, PerkinElmer, Rodgau, Germany) (Winter et al. 2018).

\section{Analysis of blood samples}

Plasma glucose concentrations were measured photometrically with an automated clinical blood gas analyzer (cobas b 123, Roche Deutschland Holding GmbH, Berlin). GGT and TG were measured by photometry with an automated clinical chemistry analyzer (Reflotron ${ }^{\circledR}$ plus Roche Deutschland Holding $\mathrm{GmbH}$, Grenzach-Wyhlen/Germany). Serum insulin, serum fructosamine and total serum magnesium concentrations were analyzed in an external laboratory (Laboklin GmbH \& Co. KG, Bad Kissingen, Germany), certified according to DIN EN ISO/IEC 17025:2005. Plasma insulin concentrations were determined by chemiluminescence (Köller et al. 2016) and serum fructosamine as well as total serum magnesium concentrations by photometry.

\section{Statistics}

All statistical analyses were performed with the statistical program IBM SPPS (version 24). P-values $<0.05$ were considered 
as statistically significant for all analyses. All data are presented as mean \pm standard deviation (SD) except for non-normally distributed data such as CNS and BCS, which are presented as median and interquartile range. A t-test for independent samples was used to compare $\left[\mathrm{Mg}^{2+}\right]_{i}$ in healthy and insulin-dysregulated horses and between sexes. Linear regression analyses with uni- and multivariable models were calculated to evaluate the influence of blood and clinical parameters on $\left[\mathrm{Mg}^{2+}\right]_{i}$. All parameters that were statistically significant in univariable models were included in a multivariable model. From this model, non-significant variables were removed stepwise according to the change of the adjusted $R^{2}$ until only significant variables were left. Model diagnostics included test for normality of residuals and visual test of homoscedasticity.

\section{Results}

\section{Horses}

The study included 38 horses with a mean age of $14 \pm 5$ years. Five of the horses were Warmbloods, 21 were ponies and 12 were different other breeds (cold-blooded horse $(n=3)$, Standardbred $(n=2)$, Arabian horse $(n=2)$, Pura Raza Española $(n=2)$, Lusitano $(n=1)$, Appaloosa $(n=1)$ and Quarter Horse $(n=1))$. Of the horses, $60.5 \%(23 / 38)$ were mares, $39.5 \%(15 / 38)$ geldings. They had a mean body weight of $419 \pm 148 \mathrm{~kg}$, a median CNS of 4 (IQR 3.75-5) and a median BCS of 8 (IGR 7-9). Signs of acute laminitis at admission were present in $7.9 \%$ (3/38). These horses were tested for EMS before discharge, after the acute laminitis phase was over. A history of laminitis without clinical signs at admission was present in $18.4 \%(7 / 38)$ of horses. The majority of horses (86.8\% (33/38)) were admitted because the owner or treating veterinarian had recommended an EMS test, most commonly due to reduced performance. Most horses were used as leisure horses, trained two to three times per week for up to one hour and had unlimited access to hay. Of all EMS horses, $26.3 \%(10 / 38)$ were kept on pasture and 50\% (19/38) received grains or additional sweet feed. According to the owners, none of the horses showed muscle tensions, nervous temper, reduced stress resistance or recurrent signs of colic. At the time of the EMS test, $97.4 \%(37 / 38)$ of horses had an Obel Score of 0, $2.6 \%(1 / 38)$ a score of 1 .

\section{Blood values and CGIT}

Total serum magnesium concentrations were within the reference range $(0.5-0.9 \mathrm{mmol} / \mathrm{L})$ in all horses. TG and GGT were slightly increased in $5.3 \%(2 / 38)$ of horses respectively. The fructosamine concentration was increased in $5.3 \%(2 / 38)$ with a mean concentration of $314.9 \pm 29.8 \mu \mathrm{mol} / \mathrm{L}$. $G_{0}$ was increased in $7.9 \%(3 / 38)$ of horses with a mean concentration of $5.13 \pm 0.63 \mathrm{mmol} / \mathrm{L}(92.4 \pm 11.3 \mathrm{mg} / \mathrm{dL})$. I $\mathrm{I}_{0}$ was within the reference range in all horses with a mean concentration of $7.5 \pm 4.3 \mu \mathrm{U} / \mathrm{mL}$. I 45 was increased in $18.4 \%(7 / 38)$ with a mean concentration of $71.8 \pm 43.1 \mu \mathrm{U} / \mathrm{mL}$. RISQI was decreased in $23.7 \%(9 / 38)$ with a mean value of $0.42 \pm 0.16$ $(\mathrm{mU} / \mathrm{L})^{0.5}$ and MIRG was increased in $21.1 \%$ (8/38) with a mean value of $4.4 \pm 2.1 \mathrm{mU}^{2} / 10 \times \mathrm{L} \times \mathrm{mg}$. Both RISQI and MIRG were not within the reference range in $15.8 \%(6 / 38)$ of horses. Glucose concentrations were decreased back to baseline in a mean time of $143 \pm 40$ minutes.

HOMA index (Fukushima et al. 1999) was categorized as stage 1 ( $\mathrm{HOMA}<2$; an insulin resistance is unlikely) in $68.4 \%(26 / 38)$ of horses, as stage 2 (HOMA 2.0-2.5; an indication of insulin resistance is given) in $10.5 \%$ (4/38) and as stage 3 (HOMA 2.5-5.0; an insulin resistance is most likely) in $21.1 \%(8 / 38)$ of horses. None of the horses was in stage 4 (HOMA > 5; an insulin resistance in present).

Intracellular magnesium concentration and correlation with insulin dysregulation

$\left[\mathrm{Mg}^{2+}\right]_{i}$ was within the reference range in $92.1 \%(35 / 38)$, below the reference ranges in two horses and above the reference ranges in one horse. $\left[\mathrm{Mg}^{2+}\right]_{i}$ was significantly lower in EMS horses $(0.24 \pm 0.074 \mathrm{mmol} / \mathrm{L})$ than in the healthy controls $(0.29 \pm 0.067 \mathrm{mmol} / \mathrm{L} ; \mathrm{P}=0.015)$. $\left[\mathrm{Mg}^{2+}\right]_{i}$ was not significantly different between sexes $(P=0.075)$.

Linear regression analyses with univariable models showed significant associations between $\left[\mathrm{Mg}^{2+}\right]_{i}$ and each of the variables $I_{0}(P=0.004, b=0.006), I_{45}(P=0.006, b=0.001)$, $I_{45-0}(P=0.008, b=0.001), \operatorname{RISQI}(P=0.009, b=-0.158)$ and MIRG $(P=0.001, b=0.017)$. The final multivariable model showed a significant influence of MIRG $(P=0.001$, $b=0.017)$ on $\left[\mathrm{Mg}^{2+}\right]_{i}$. All other variables turned out to be not significant after considering the effect of MIRG. Thus, the $\left[\mathrm{Mg}^{2+}\right]_{\mathrm{i}}$ can be predicted most accurately in EMS horses from MIRG where MIRG increases by 1 represent $\left[\mathrm{Mg}^{2+}\right]_{i}$ increases by $0.017 \mathrm{mmol} / \mathrm{L}$ (Figure 1).

\section{Discussion}

In this study, horses with equine metabolic syndrome had $\left[\mathrm{Mg}^{2+}\right]_{i}$ values that were by and large within the previously established reference range. However, $\left[\mathrm{Mg}^{2+}\right]_{i}$ values were generally lower in horses with EMS than in healthy control horses.

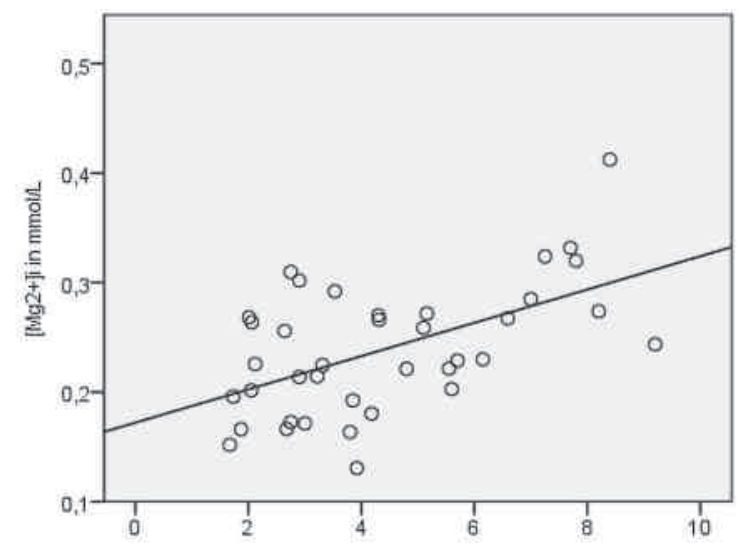

Fig. 1 Scatter plot displaying the linear relationship between the modified insulin-to-glucose ratio (MIRG) in $\mathrm{mU}^{2} / 10 \times \mathrm{L} \times \mathrm{mg}$ and the intracellular magnesium concentration $\left[\mathrm{Mg}^{2+}\right]_{\mathrm{i}}$ in $\mathrm{mmol} / \mathrm{L}$ in horses with EMS. | Streudiagramm, das die lineare Beziehung zwischen dem modifizierten Insulin-zu-Glucose-Verhältnis (MIRG) in $m U^{2} / 10 \times L \times m g$ und der intrazellulären Magnesiumkonzentration $\left[\mathrm{Mg}^{2+}\right]_{i}$ in $\mathrm{mmol} / \mathrm{L}$ bei Pferden mit EMS zeigt. 
The second important finding was a positive correlation between $\left[\mathrm{Mg}^{2+}\right]_{i}$ and $\beta$-cell function within this group of EMS horses. Regression analysis revealed that if MIRG increased by $1,\left[\mathrm{Mg}^{2+}\right]_{i}$ increased by $0.017 \mathrm{mmol} / \mathrm{L}$. This means that EMS horses with a higher insulin secretion from $\beta$-cells have higher $\left[\mathrm{Mg}^{2+}\right]_{i}$.

In human medicine, especially in the pathophysiology of diabetes mellitus type II, the role of magnesium is well defined. An inverse relationship between serum magnesium concentration and the incidence of diabetes mellitus type 2 was ascertained. Several studies showed that up to $77 \%$ of type 2 diabetics are affected by magnesium deficiency (Pham et al. 2007, Sales et al. 2011 , Rasheed et al. 2012). Moreover, the supplementation with magnesium reduces the risk to develop diabetes in humans (Rasheed et al. 2012, Yang et al. 1999, He et al. 2006). Magnesium supplementation has a positive influence on different parameters related to the control of blood glucose concentration and counteracts the development of an insulin resistance (Volpe 2008, Günther 2010, Hruby et al. 2017). Interestingly, previous studies in humans have shown, that inducing a magnesium deficiency can reduce insulin sensitivity; whereas, a four week magnesium supplementation improved glucose handling in elderly people without diabetes (Paolisso et al. 1992, Nadler et al. 1993). This suggests an influence of magnesium on glucose metabolism irrespectively of whether the test persons already have clinical diabetes.

In EMS, research on the role of magnesium has been very scarce and not that consistent. The parallels between EMS and diabetes mellitus type II could suggest a similar role for magnesium in both diseases. In the present study, we discovered a significantly lower $\left[\mathrm{Mg}^{2+}\right]_{i}$ in EMS horses identified by decreased insulin sensitivity, but values were still within the previously established reference range (Winter et al. 2018). One possible explanation for this relatively small difference in $\left[\mathrm{Mg}^{2+}\right]_{\mathrm{i}}$ could be the comparatively high magnesium intake with the typical equine diet. It is well established in humans, that oral magnesium supplementation can counteract the development of intracellular magnesium deficiency (Thomas et al. 2000). A second possible explanation for the relatively small drop in $\left[\mathrm{Mg}^{2+}\right]_{i}$ in EMS patients might be related to the severity of ID. In human medicine, a distinction is made between impaired glucose tolerance (IGT), impaired fasting glycaemia (IFG), also called "non-diabetic fasting hyperglycemia", and diabetes mellitus with hyperglycemia (Alberti and Zimmet 1998). In the above-mentioned studies on the relationship between magnesium and ID in humans (Paolisso and Barbagallo 1997, Pham et al. 2007, Chaudhary et al. 2010, Rasheed et al. 2012, Kao et al. 1999, de Valk 1999) patients were classified as diabetes mellitus type II. Hence, these patients showed hyperglycemia at rest and a more pronounced ID than the horses in our study. Glucose baseline concentrations were within the reference range in $92.1 \%$ (35/38) of our horses and all showed physiological baseline concentrations of insulin. In addition, factors that contribute to magnesium deficiency in humans (renal wasting and reduced intake) are not relevant in horses. Perhaps a more severe ID or insulin resistance would be associated with a more distinct magnesium deficiency. In addition to altered glucose and insulin levels, laminitis is an important consequence of pronounced ID. Only $7.9 \%$ (3/38) of the horses showed acute laminitis when admitted to our clinic and were examined for our study before discharge. A history of laminitis was present in only $18.4 \%$ $(7 / 38)$ of the horses.

The theory that a rather mild ID can be made responsible for the small decreases in $\left[\mathrm{Mg}^{2+}\right]_{i}$ in the EMS horses of our study is supported by the finding that the decreased $\left[\mathrm{Mg}^{2+}\right]_{\mathrm{i}}$ in EMS horses was partially reversed by increased secretion of insulin from pancreatic $\beta$-cells. The latter can be postulated because horses with higher MIRG suffered less from lower $\left[\mathrm{Mg}^{2+}\right]_{i}$. A higher MIRG, in turn, is an indicator of the ability of the pancreas to alleviate the consequences of insulin resistance by increased secretion of insulin. The increased secretion of insulin may subsequently rescue the insulin signaling pathway, leading to an increased activation of the phosphoinositide 3-kinase (PI3K) by the insulin receptor. PI3K then further activates protein kinase $B(P K B)$, which induces a higher activity of the phosphodiesterase. As a result, the CAMP concentration decreases and the protein kinase $A(P K A)$ is less active. Less active PKA results in less phosphorylation of the $\mathrm{Na}^{+} / \mathrm{Mg}^{2+}$ exchanger SLC41A1 and, as an end result, in less efflux of $\mathrm{Mg}^{2+}$ out of the cell (Mastrototaro et al. 2015, Zmuda-Trzebiatowska et al. 2006, Ahmed et al. 2010). Via this pathway, insulin application is able to retain magnesium in the intracellular compartment in non-diabetic humans with a decline in plasma and an increase in intracellular magnesium concentration (Paolisso et al. 1986). Vice versa, inhibition of SLC41A1 by insulin becomes ineffective in decompensated insulin resistance with increased glucose baseline concentration, provoking an intracellular magnesium deficit.

Similar to diabetes, supplementation with magnesium has also been investigated as a treatment option in horses with ID with varying success. Depending on the source, the daily requirement for elemental magnesium in adult horses is between 12.5$20 \mathrm{mg} / \mathrm{kgBW} /$ day. For high performance horses (pregnancy, lactation, sports), demand can increase to as much as $30 \mathrm{mg} /$ kg BW/day (Hintz et al. 1973, Horses NRCCoNRo 2007). For oral supplementation of horses, the following dosages are recommended: $30-50 \mathrm{mg} / \mathrm{kg}$ of magnesium oxide BW/day, 80 $100 \mathrm{mg} / \mathrm{kg}$ of magnesium sulfate BW/day or $125-300 \mathrm{mg} / \mathrm{kg}$ of magnesium-aspartate hydrochloride BW/day (Toribio 2010). In one study by Chameroy et al., the effects of a feed additive containing chromium and $8.8 \mathrm{~g}$ magnesium oxide/proteinate per horse on insulin sensitivity have been investigated. No differences were found in the blood levels of glucose and insulin immunoreactivity or in the insulin sensitivity of peripheral tissues (Chameroy et al. 2011). Another study showed improvements in the CGIT (shorter positive phase duration of the glucose curve) in 3/5 horses and a trend for a lower fructosamine concentration after three months of supplementation with $30 \mathrm{mg} / \mathrm{kg}$ magnesium as magnesium-aspartate hydrochloride (Winter et al. 2016). Because of the small sample size and limited repeatability of the glucose curve, results of the latter study should be interpreted with care. It is possible that horses with ID have an increased need of magnesium and a dosage above the usual requirements is necessary to induce changes in insulin sensitivity. Furthermore, studies in cats and rats have shown that magnesium-aspartate hydrochloride is significantly better absorbed from the gastrointestinal tract than magnesium sulfate, chloride or aspartate (Classen et al. 1973). In addition, magnesium-aspartate hydrochloride has 
a better oral bioavailability than magnesium oxide in humans (Mühlbaver et al. 1991). Comparable examinations in horses have not been carried out so far. Therefore, differences in study design may explain varying results.

The results of the present study confirm earlier findings from human medicine in that serum concentrations of magnesium are an insensitive marker of magnesium deficiency. Therefore, different methods for the determination of $\left[\mathrm{Mg}^{2+}\right]_{i}$ in multiple tissues and blood cells have been developed (Reinhart et al. 1987, Schwinger et al. 1987, Huijgen et al. 1998). Values obtained by these techniques in skeletal (Princi et al. 1997), vascular smooth muscle, cardiac muscle (Niemela et al. 1997), lymphocytes and erythrocytes (Princi et al. 1997, Delva et al. 2006, Basso et al. 2000) reflect the actual situation in the cell better than the serum magnesium concentration.

Different tests have been described in literature to diagnose ID in horses. The CGIT, which was used in this study, is easy to perform and a commonly used test. In comparison, the frequently sampled glucose insulin tolerance test with minimal model analysis (FSIGTT ${ }_{M M}$ ) and the euglycaemic hyperinsulinaemic clamp (EHC) technique are more precise, but also more elaborate. They are therefore not used for routine diagnostics (Knowles et al. 2012). For our study, it was important to elucidate if alterations in insulin sensitivity determined with an easy-to-use test could be correlated with magnesium metabolism. The OST (oral sugar test) and the OGTT (oral glucose tolerance test) (Pratt-Phillips et al. 2015, Schuver et al. 2014) also belong in this category. However, the values of these tests are influenced by gastric emptying, glucose absorption and hepatic glucose trapping (Kronfeld et al. 2005). Furthermore, the OST is primarily a test for $\beta$-cell response rather than a test for insulin sensitivity (Lindåse et al. 2017). It was found to be highly specific but had a poor sensitivity for diagnosing insulin resistance (Dubar et al. 2016). Some authors report a good correlation of OGTT with intravenous glucose tests, but others report strong variations in the insulin response (Pratt-Phillips et al. 2015, Schuver et al. 2014). The sensitivity of the CGIT (positive phase duration of the glucose curve $>45$ minutes) was $85.7 \%$ and specificity was $40 \%$, whereas for $\mathrm{I}_{45}>100 \mu \mathrm{lU} / \mathrm{mL}$ sensitivity and specificity were $28.5 \%$ and $100 \%$, respectively, when compared to the FSIGTT ${ }_{M M}$. Hereby the CGIT showed better agreement with the FSIGTT ${ }_{M M}$ than the OST in previous studies. Calculated parameters for the glucose curve of the CGIT should be interpreted with care, as they had low repeatability, whereas the parameters for the insulin curve had high repeatability. There was an effect of breed (Standardbred versus Icelandic horse) as well as stress on the glucose dynamics, but not on the insulin dynamics of the CGIT (Bröjer et al. 2013). The insulin concentrations therefore seem to be a more reliable parameter to diagnose insulin dysregulation. In our study, glucose dynamics have been used as criteria to diagnose insulin dysregulation and the influences mentioned above could have led to imprecise classifications. In the multivariable model only MIRG had a significant influence on $\left[\mathrm{Mg}^{2+}\right]_{\mathrm{i}}$. This is interesting, since proxy measures are usually recommended as screening tests, while dynamic tests are preferred for the diagnosis of insulin resistance (Frank et al. 2014). Nevertheless, proxies showed a better correlation with results of the FSIGTT $_{M M}$ than basal insulin concentration and HOMA-IR (Treiber et al. 2005). It would be of interest to examine the influence of a magnesium supplementation on parameters of ID, including MIRG.
Finally, this study was not able to identify sex differences in the magnesium status of EMS horses. In human medicine, a higher incidence of hypomagnesemia could be shown in women compared with men at a 2-to-1 ratio (Pham et al. 2005, Sheehan 1991). In addition, men with diabetes may have higher levels of ionized magnesium (Mikhail and Ehsanipoor 1999). In the horses of the present study, however, $\left[\mathrm{Mg}^{2+}\right]_{i}$ was not significantly different between sexes. It remains to be shown whether the latter may be attributable to the fact that all male horses of the present study (15/38) were geldings and, as such, not under the metabolic influence of testosterone.

In conclusion, results of this study showed a lower intracellular magnesium concentration in horses with ID without sex differences. We further demonstrated a positive correlation between the intracellular magnesium concentration and the proxy MIRG. Further studies should examine the role of magnesium metabolism in horses with metabolic syndrome, especially in horses with more pronounced insulin resistance.

\section{List of abbreviations}

$\begin{array}{ll}\text { BCS } & \text { body condition score } \\ \text { BW } & \text { body weight } \\ \text { CAMP } & \text { cyclic adenosinmonophosphate } \\ \text { CGIT } & \text { combined glucose insulin tolerance test } \\ \text { CNS } & \text { cresty neck score } \\ \text { EHC } & \text { euglycaemic hyperinsulinaemic clamp } \\ \text { EMS } & \text { equine metabolic syndrome } \\ \text { FSIGTT } & \text { frequently sampled glucose insulin tolerance } \\ & \text { test with minimal model analysis } \\ \text { G } & \text { baseline glucose } \\ \text { GGT } & \text { gamma-glutamyl transferase } \\ \text { HOMA Index } & \text { homeostasis model assessment for insulin re- } \\ & \text { sistance } \\ \text { I0 } & \text { baseline insulin } \\ \text { I } & \text { insulin after 45 minutes } \\ \text { I }_{45-0} & \text { insulin difference } \\ \text { ID } & \text { insulin dysregulation } \\ \text { IFG } & \text { impaired fasting glycaemia } \\ \text { IGT } & \text { impaired glucose tolerance } \\ \text { IQR } & \text { inter quartile range } \\ {[\text { Mg }} & \text { intracellular magnesium concentration } \\ \text { MIRG } & \text { modified insulin-to-glucose ratio } \\ \text { OGTT } & \text { oral glucose tolerance test } \\ \text { OST } & \text { oral sugar test } \\ \text { PI3K } & \text { phosphoinositide 3-kinase } \\ \text { PKA } & \text { protein kinase A } \\ \text { PKB } & \text { protein kinase B } \\ \text { RISQI } & \text { reciprocal inverse square of insulin } \\ \text { SD } & \text { standard deviation } \\ \text { SLC41A1 } & \text { solute carrier family 41, member A1 } \\ \text { TG } & \text { triglycerides } \\ & \end{array}$

\section{Conflict of interest statement}

The authors declare not to be subject to any conflicts of interest in regard to drugs or technical equipment used in the present study. 


\section{Animal Welfare Statement}

The study was not declared according to the German Animal Protection Law $\S 8,1$ because all blood samples were taken as part of a routine examination in horses presented with typical clinical sign of Equine Metabolic Syndrome (EMS).

\section{Statement of informed consent}

All horse owners approved the use of their horses' blood samples in this study in writing.

\section{Acknowledgment}

The authors would like to thank Sabita Stöckle for her assistance in the clinical examinations. The measurement of the intracellular magnesium concentrations have been performed in the Institute of Veterinary Physiology; Freie Universität Berlin. No external funding was provided.

\section{References}

Ahmed K., Tunaru S., Tang C., Müller M., Gille A., Sassmann A., Hanson J., Offermanns S. (2010) An autocrine lactate loop mediates insulin-dependent inhibition of lipolysis through GPR81. Cell metab. 11, 311-319; DOI 10.1016/i.cmet.2010.02.012

Alberti K. G. M. M., Zimmet P. Z. (1998) Definition, diagnosis and classification of diabetes mellitus and its complications. Part 1: diagnosis and classification of diabetes mellitus. Provisional report of a WHO consultation. Diabetic Med. 15, 539-553; DOI 10.1002/ (SICI) 1096-9136(199807) 15:7<539::AID-DIA668>3.0.CO;2-S

Arnaud M. J. (2008) Update on the assessment of magnesium status. British J. Nutr. 99, 24-36; DOI 10.1017/S000711450800682X

Basso L. E., Ubbink J. B., Delport R. (2000) Erythrocyte magnesium concentration as an index of magnesium status: a perspective from a magnesium supplementation study. Clinica chim. acta 291, 1-8; DOI 10.1016/s0009-8981 (99)00168-0

Bröjer J., Lindåse S., Hedenskog J., Alvarsson K., Nostellet K. (2013) Repeatability of the combined glucose-insulin tolerance test and the effect of a stressor before testing in horses of 2 breeds. J. Vet. Int. Med. 27, 1543-1550; DOI 10.1111/jvim.12172

Carter R. A., Geor R. J., Staniar W. B., Cubitt T. A., Harris P. A. (2009) Apparent adiposity assessed by standardised scoring systems and morphometric measurements in horses and ponies. Vet. J. 179, 204-210; DOI 10.1016/i.tvil.2008.02.029

Chameroy K., Frank N., Elliott S., Boston R. C. (2011) Effects of a supplement containing chromium and magnesium on morphometric measurements, resting glucose, insulin concentrations and insulin sensitivity in laminitic obese horses. Equine Vet. J. 43, 494-499. DOI 10.1111/j.2042-3306.2010.00302.x

Chaudhary D. P., Sharma R., Bansal D. D. (2010) Implications of Magnesium Deficiency in Type 2 Diabetes: A Review. Biolog. Trace Elem. Res. 134, 119-129; DOI 10.1007/s12011-009-8465-z

Classen H., Marquardt P., Späth M., et al. (1973) Vergleichende tierexperimentelle Untersuchungen über die Resorption von Magnesium als Sulfat, Chlorid, Aspartat und Aspartat-Hydrochlorid aus dem Magen-Darm-Trakt. Arzneim. Forsch./Drug Res. 23, 267-271

Delva P., Degan M., Trettene M., Lechi A. (2006) Insulin and glucose mediate opposite intracellular ionized magnesium variations in human lymphocytes. Endocrinology 190, 711-718; DOI 10.1677/ joe. 1.06389

de Valk H. W. (1999) Magnesium in diabetes mellitus. Netherl. J. Med. 54, 139-146; DOI 10.1016/S0300-2977(99)00005-4
Dunbar L., Mielnicki K., Dembek K., Toribio R. E., Burns T. A. (2016) Evaluation of Four Diagnostic Tests for Insulin Dysregulation in Adult Light-Breed Horses. J. Vet. Int. Med. 30, 885-891; DOI 10.1111//jvim. 13934

Eiler H., Frank N., Andrews F. M., Oliver J. W., Fecteavet K. A. (2005) Physiologic assessment of blood glucose homeostasis via combined intravenous glucose and insulin testing in horses. Am. J. Vet. Res. 66, 1598-1604; DOI 10.2460/ajvr.2005.66.1598

Frank N., Geor R. J., Bailey S. R., Durham A. E., Johnson P. J. (2010) Equine Metabolic Syndrome. J. Vet. Int. Med., 467-475; DOI 10.1111/j.1939-1676.2010.0503.x

Frank N., Tadros E. (2014) Insulin dysregulation. Equine Vet. J. 46, 103-112; DOI 10.1111/evj.12169

Fukushima M., Taniguchi A., Sakai M., Doi K., Nagasaka S., Tanaka H. (1999) Homeostasis model assessment as a clinical index of insulin resistance. Comparison with the minimal model analysis. Diabet. Care 22, 1911-1912

Günther T. (2010) The biochemical function of $\mathrm{Mg}^{2+}$ in insulin secretion, insulin signal transduction and insulin resistance. Magnesium Res. 23, 5-18

He K., Song Y., Belin R. J., Chen Y. (2006) Magnesium intake and the metabolic syndrome: epidemiologic evidence to date. J. Cardiometab. Syndr. 1, 351-355; DOI 10.1684/mrh.2009.0195

Henneke D., Potter G., Kreider J., Yeates B. F. (1983) Relationship between condition score, physical measurements and body fat percentage in mares. Equine Vet. J. 15, 371-372; DOI 10.1111/ j.2042-3306.1983.tb01826.x

Hintz H., Schryver H. (1973) Magnesium, calcium and phosphorus metabolism in ponies fed varying levels of magnesium. J. Animal Sci. 37, 927-930; DOI 10.2527/jas 1973.374927x

Hruby A., Guasch-Ferré M., Bhupathiraju S. N., Manson J. E., Willett W. C., McKeown N. M., Huet F. B. (2017) Magnesium Intake, Quality of Carbohydrates, and Risk of Type 2 Diabetes: Results From Three US Cohorts. Diabet. Care 40, 1695-1702; DOI 10.2337/dc17-1143

Huijgen H. J., Sanders R., Van Olden R. W., Klous M. G., Gaffar F. R., Sanders G. T. B. (1998) Intracellular and extracellular blood magnesium fractions in hemodialysis patients; is the ionized fraction a measure of magnesium excess? Clin. Chem. 44, 639-648; DOI 10.1093/clinchem/44.3.639

Itani S. I., Zhou Q., Pories W. J., MacDonald K. G., Dohm G. L. (2000) Involvement of protein kinase $C$ in human skeletal muscle insulin resistance and obesity. Diabetes 49, 1353-1358; DOI 10.2337/diabetes.49.8.1353

Kao W. H. L., Folsom A. R., Nieto F. J., Mo J.-P., Watson R. L., Brancati F. L. (1999) Serum and dietary magnesium and the risk for type 2 diabetes mellitus - The atherosclerosis risk in communities study. Arch. Int. Med. 159, 2151-2159; DOI 10.1001/archinte.159.18.2151

Knowles E., Withers J., Mair T. (2012) Increased plasma fructosamine concentrations in laminitic horses. Equine Vet. J. 44, 226-229; DOI 10.1111/j.2042-3306.2011.00419.x

Köller G., Bassewitz K., Schusser G. (2016) Referenzbereiche von Insulin, insulinähnlichem Wachstumsfaktor 1 (IGF-1) und adrenokortikotropem Hormon bei Ponys. Tierärztl. Praxis G 44, 19-25; DOI 10.15653/TPG-150428

Kronfeld D. S., Treiber K. H., Geor R. J. (2005) Comparison of nonspecific indications and quantitative methods for the assessment of insulin resistance in horses and ponies. J. Am. Vet. Med. Assoc. 226, 712-719; DOI 10.2460/javma.2005.226.712

Lindåse S., Nostell K., Söder J., Bröjer J. (2017) Relationship Between $\beta$-cell Response and Insulin Sensitivity in Horses based on the Oral Sugar Test and the Euglycemic Hyperinsulinemic Clamp. J. Vet. Int. Med. 31, 1541-1550; DOI 10.1111/jvim.14799

Mastrototaro L., Tietjen U., Sponder G., Vormann J., Aschenbach J. R., Kolisek M. (2015) Insulin modulates the $\mathrm{Na}^{+} / \mathrm{Mg}^{2+}$ exchanger SLC41Al and influences $\mathrm{Mg}^{2+}$ efflux from intracellular stores in transgenic HEK293 cells. Nutrition 145, 2440-2447; DOI 10.3945/jn.115.213918

Mikhail N., Ehsanipoor K. (1999) lonized serum magnesium in type 2 diabetes mellitus: its correlation with total serum magnesium and hemoglobin A1c levels. South. Med. J. 92, 1162-1 166; DOI 10.1097/00007611-199912000-00005 
Mühlbaver B., Schwenk M., Coram W., Antonin K. H., Etienne P., Bieck P. R., Douglas F. L. (1991) Magnesium-L-aspartate-HCl and magnesium-oxide: bioavailability in healthy volunteers. Europ. J. Clin. Pharmacol. 40, 437-438

Nadler J. L., Buchanan T., Natarajan R., Antonipillai I., Bergman R., Rude R. (1993) Magnesium deficiency produces insulin resistance and increased thromboxane synthesis. Hypertension 21, 1024 1029; DOI 10.1161/01.HYP.21.6.1024

National Research Council (2007) Nutrient Requirements of Horses: Sixth Revised Edition. Washington, DC: The National Academies Press, 1-360; DOI 10.17226/11653

Niemela J. E., Csako G., Bui M. N., Elin R. J. (1997) Gender-specific correlation of platelet ionized magnesium and serum low-density-lipoprotein cholesterol concentrations in apparently healthy subjects. J. Laborat. Clin. Med. 129, 89-96; DOI 10.1016/S00222143(97)90165-7

Obel N. (1948) Studies on the histopathology of acute laminitis. Almqvist \& Wiksells, Uppsala. 1-95

Paolisso G., Barbagallo M. (1997) Hypertension, diabetes mellitus, and insulin resistance - The role of intracellular magnesium. Am. J. Hypertens. 10, 346-355; DOI 10.1016/S0895-7061 (96)00342-1

Paolisso G., Sgambato S., Gambardella A., Pizza G., Tesauro P., Varricchio M., D'Onofrio F. (1992) Daily magnesium supplements improve glucose handling in elderly subjects. Am. J. Clin. Nutrit. 55, 1161-1167; DOI 10.1093/ajcn/55.6.1161

Paolisso G., Sgambato S., Passariello N., Giughano D., Scheen A., $D^{\prime}$ Onofrio F., Lefèbvre P. J. (1986) Insulin induces opposite changes in plasma and erythrocyte magnesium concentrations in normal man. Diabetologia 29, 644-647

Pham P.-C. T., Pham P.-M., Pham P.-A., Pham S. V., Pham H. V., Miller J. M., Yanagawa N., Pham P. T. T. (2005) Lower serum magnesium levels are associated with more rapid decline of renal function in patients with diabetes mellitus type 2. Clin. Nephrol. 63, 429436; DOI 10.5414/cnp63429

Pham P.-C. T., Pham P.-M. T., Pham S. V., Miller J. M., Pham P.-T. T. (2007) Hypomagnesemia in patients with type 2 diabetes. Clin. J. Am. Soc. Nephrol. 2, 366-373; DOI 10.2215/CJN.02960906

Ponder S. W., Brouhard B. H., Travis L. B. (1990) Hyperphosphaturia and Hypermagnesuria in children with IDDM. Diabetes Care 13, 437-441; DOI 10.2337/diacare. 13.4.437

Pratt-Phillips S. E., Geor R. J., McCutcheon L. J. (2015) Comparison among the euglycemic-hyperinsulinemic clamp, insulin-modified frequently sampled intravenous glucose tolerance test, and oral glucose tolerance test for assessment of insulin sensitivity in healthy Standardbreds. Am J. Vet. Res. 76, 84-91; DOI 10.2460/ ajvr.76. 1.84

Princi T., Artero M., Malusà N., Uxa L., Livia V., Reina G. (1997) Serum and intracellular magnesium concentrations in intoxicated chronic alcoholic and control subjects. Drug Alcohol Depend. 46, 119-122; DOI 10.1016/S0376-8716(97)00037-9

Rasheed H., Elahi S., Ajaz H. (2012) Serum magnesium and atherogenic lipid fractions in type II diabetic patients of Lahore, Pakistan. Biolog. Trace Elem. Res. 148, 165-169; DOI 10.1007/s1201 1-012-9361-5

Reinhart R. A., Marx J. J., Haas R. G., Desbiens N. A. (1987) Intracellular magnesium of mononuclear cells from venous blood of clinically healthy subjects. Clin. Chim. Acta 167, 187-195; DOI 10.1016/0009-8981(87)90371-8
Romani A. M., Maguire M. E. (2002) Hormonal regulation of $\mathrm{Mg}^{2+}$ transport and homeostasis in eukaryotic cells. Biometals 15, 271283; DOI 10.1023/a:1016082900838

Sales C. H., Pedrosa L. F. C., Lima J. G., Lemos T. M. A. M., Collia C. (2011) Influence of magnesium status and magnesium intake on the blood glucose control in patients with type 2 diabetes. Clin. Nutr. 30, 359-364; DOI 10.1016/i.clnu.2010.12.011

Schuver A., Frank N., Chameroy K. A., Elliot S. E. (2014) Assessment of insulin and glucose dynamics by using an oral sugar test in horses. J. Equine Vet. Sci. 34, 465-470; DOI 10.1016/i. jevs.2013.09.006.

Schwinger R., Antoni D., Guder W. (1987) Simultaneous determination of magnesium and potassium in lymphocytes, erythrocytes and thrombocytes. J. Trace Elem. Electroly. Health Dis. 1, 89-98

Sheehan J. (1991) Magnesium deficiency and diabetes mellitus. Magnesium and trace elements 10, 215-219

Stewart A. J., Hardy J., Kohn C. W., Toribio R. E., Hinchcliff K. W., Silver B. (2004) Validation of diagnostic tests for determination of magnesium status in horses with reduced magnesium intake. Am. J. Vet. Res. 65, 422-430; DOI 10.2460/ajvr.2004.65.422

Thomas J., Millot J. M., Sebille S., A.-M. Delabroise A.-M., Thomas E., Manfait M., Arnaud M. J. (2000) Free and Total Magnesium in Lymphocytes of Migraine Patients - Effect of Magnesium-Rich Mineral Water Intake. Clin. Chim. Acta 295 (1-2), 63-75; DOI 10.1016/S0009-8981(00)00186-8

Toribio R. (2010) Magnesium and disease. Equine internal medicine $3^{\text {rd }}$ edition St Louis (MO): Saunders 1291-1295

Treiber K. H., Kronfeld D. S., Hess T. M., Boston R. C., Harris P. A. (2005) Use of proxies and reference quintiles obtained from minimal model analysis for determination of insulin sensitivity and pancreatic beta-cell responsiveness in horses. Am. J. Vet. Res. 66, 2114-2121; DOI 10.2460/ajvr.2005.66.2114

Volpe S. L. (2008) Magnesium, the metabolic syndrome, insulin resistance, and type 2 diabetes mellitus. Crit. Re. Food Sci. Nutrit. 48, 293-300; DOI 10.1080/10408390701326235

Vormann J. (2003) Magnesium: nutrition and metabolism. Molec. Aspects Med. 24, 27-37; DOI 10.1016/S0098-2997(02)00089-4

Winter J. C., Liertz S., Merle R., Aschenbach J. R., Gehlen H. (2016) Oral supplementation of magnesium aspartate hydrochloride in horses with Equine Metabolic Syndrome. Pferdeheilkunde 32, 372-377; DOI 10.21836/PEM20160410

Winter J. C., Sponder G., Merle R., Aschenbach J. R., Gehlen H. (2018) Intracellular free magnesium concentration in healthy horses. J. Anim. Physiol. Anim. Nutr 1351-1356; DOI 10.1111/ ipn. 12921

Yang C. Y., Chiu H., Cheng M., Tsai S. S., Hung C. F., Tseng Y. T. (1999) Magnesium in drinking water and the risk of death from diabetes mellitus. Magnesium Res. 12, 131-137

Yoshimura M., Oshima T., Hiraga H., Nakano Y., Matsuura H., Yamagata T., Shiode N., Kato M., Kambe M., Kailyama G. (1998) Increased cytosolic free $\mathrm{Mg}^{2+}$ and $\mathrm{Ca}^{2+}$ in platelets of patients with vasospastic angina. Am. J. Physiol.-Regul., Integr. Comp. Physiol. 274, R548-R554; DOI 10.1152/ajpregu.1998.274.2.R548

Zmuda-Trzebiatowska E., Oknianska A., Manganiello V., Degermann E. (2006) Role of PDE3B in insulin-induced glucose uptake, GLUT4 translocation and lipogenesis in primary rat adipocytes. Cell. signall. 18, 382-390; DOI 10.1016/i.cellsig.2005.05.007 